\section{Multivariance solutions for designing new levels of coal mines}

The Mining-Geology-Petroleum Engineering Bulletin UDC: 622.272.31: 622.33: 622.27 DOI: $10.17794 /$ rgn.2020.2.3

Original scientific paper

\author{
Vasyl Lozynskyi ${ }^{1,2}$, Volodymyr Medianyk ${ }^{3}$, Pavlo Saik ${ }^{4,5}$, \\ Kanay Rysbekov ${ }^{6}$, Maksym Demydov ${ }^{7,8}$ \\ ${ }^{1}$ Dnipro University of Technology, Department of Mining Engineering and Education, Yavornytskoho Ave 19, UA-49005 Dnipro, Ukraine, \\ ${ }^{2}$ Institute of Postgraduate Education of NUWEE, 24 Serpnia St 11, UA-33000 Rivne, Ukraine, \\ http://orcid.org/0000-0002-9657-0635 \\ ${ }^{3}$ Dnipro University of Technology, Department of Mining Engineering and Education, Yavornytskoho Ave 19, UA-49005 Dnipro, Ukraine, \\ http://orcid.org/0000-0001-5403-5338 \\ ${ }^{4}$ Dnipro University of Technology, Department of Mining Engineering and Education, Yavornytskoho Ave 19, UA-49005 Dnipro, Ukraine, \\ ${ }^{5}$ Institute of Postgraduate Education of NUWEE, 24 Serpnia St 11, UA-33000 Rivne, Ukraine, \\ http://orcid.org/0000-0001-7758-1083 \\ ${ }^{6}$ Satbayev University, Mining Department, Satpayev St 22a, KZ-50013 Almaty, Kazakhstan, \\ http://orcid.org/0000-0003-3959-550X \\ ${ }^{7}$ Dnipro University of Technology, Department of Mining Engineering and Education, Yavornytskoho Ave 19, UA-49005 Dnipro, Ukraine, \\ ${ }^{8}$ Geological Concern "Geobit", 10 Żurawiec St., PL-32500, Chrzanów, Poland \\ http://orcid.org/0000-0002-8000-4639
}

\begin{abstract}
In this article, variants of technological designing of new mining enterprise levels for obtaining the skills of engineering task execution are considered. The complex approach for the justification of a mine's parameters is examined. The combinations of quantitative and qualitative parameters for designing new coal-face and preparation works, transport, ventilation, and draining-out of gases, pumping, and mineral deposits while keeping cost reduction in mind for all stages of mining enterprise operations are presented. The obtained results allow us to lay the foundations for optimizing the parameters of the development system and the rational order for the coal reserves, under the changing mining and geological conditions of coal field deposit development. Conclusions regarding the implementation of the multivariance solutions in new coal mine level designing are made on the basis of undertaken investigations. The obtained results with sufficient accuracy in a practical application can be used to determine the development of new coal mine levels.
\end{abstract}

\section{Keywords:}

coal mines, mining, multivariance, technological schemes

\section{Introduction}

Coal is the main fossil fuel used in the power generation. At the same time, coal is the most abundant energy resource and will continue to be the dominant energy source for the next 20-40 years, but in the Ukraine even up to 50-60 years (Piwniak et al., 2005; Petlovanyi et al., 2018). The analysis of coal deposit development under modern conditions shows the necessity of new solutions for a line of problems to provide safety in mine exploitation, complex development of mineral resources and protection of the environment (Vivcharenko, 2012; Bondarenko et al., 2019; Yu et al., 2019; Kovalevska et al., 2019).

Corresponding author: Vasyl Lozynskyi

lvg.nmu@gmail.com
Assessment of new coal mine levels at the stage of their design, development and operation should take into account the current and future needs of the national economy (Piwniak et al., 2007). From this point of view, the volume of reserves and mineral content in them play the main role (Griadushchiy et al., 2007). Today, the world community determines the conditions of ecological and rational basis for natural resource development (Murray 1997; Jain et al., 2016; Petlovanyi 2019b). New engineering solutions, novel scientific and technological achievements, and the analysis of production experience all create a good basis for us to prototype mining facilities (Malanchuk et al., 2019a).

Further development of coal seams also requires a competent approach to the designing of mining operations and planning new levels (Kalybekov et al., 2019; Galiyev et al., 2019). All techno-economic indicators taken for calculation should be comparable in their ap- 


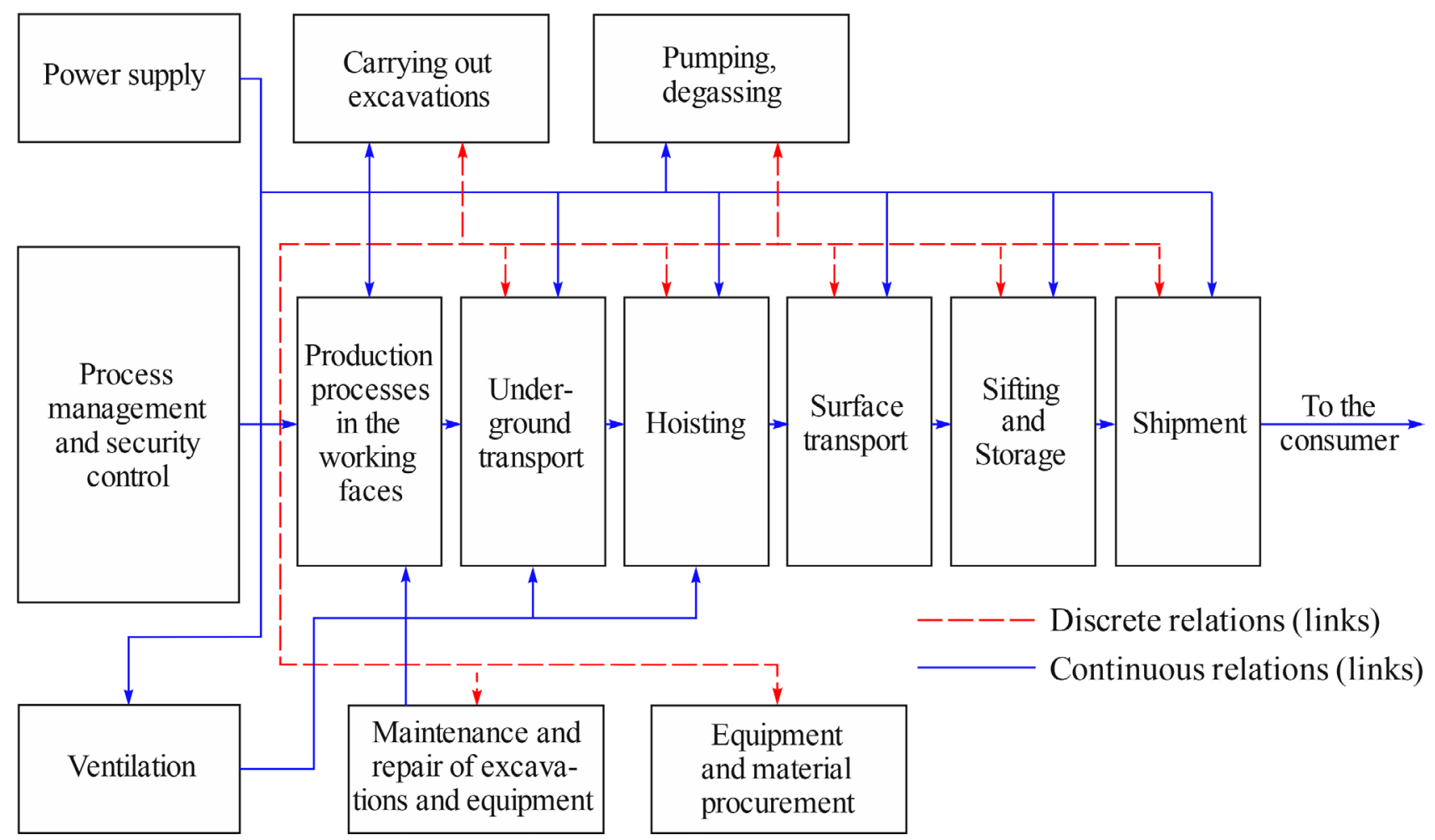

Figure 1: Block diagram of operation processes technological connection; solid graphs denote continuous connections, dotted graphs represent discrete ones

plicability to the geological and mining-technical conditions of the projected level according to the time of their use, the quality and quantity of produced products, deep mining, etc. (Lozynskyi et al., 2016; Mustafin et al., 2019). Therefore, more and more attention is paid to the analysis of multivariance solutions in the design of any mining process as a condition for getting stable technical and economic indicators.

Analytical engineering calculations and solutions allow for the assessment of the real coal and gas reserves, so necessary for the country (Singhal, 1985; Bustin, 1988; Maldynova et al., 2018). After all, when including the natural resource reserves on the coal mine balance sheet, where it is possible to justify mine development, and then work them out technically, ecologically and in a cost-effective way, the geomechanics of the seams and rock massifs faulting, the complexity of coal excavation and other associated minerals, including methane gas become irrelevant (Khomenko et al., 2018; Saik et al, 2018; Zhao,et al., 2019).

\section{Literature Review}

The qualitative and quantitative parameters of the mine reflect these technological links. It is not difficult to establish this according to the technological schemes and methods of opening-up of a mine and ventilation, the preparation and transport schemes, the mining and security methods and maintaining excavations and the types of hoisting, etc. (Bondarenko et al., 2014; Stupnik et al, 2015; Aitkazinova et al., 2016; Kalinichenko et al., 2018).

Interrelationships of the quantitative parameters, such as the mine thickness with the number of working faces and the loading on one face, the speed of carrying out the excavations with the speed of working faces, the crosssections of the excavations with the load on the working face, the amount of air supplied to the mine (the parameters of the mine fans), with the productivity rate of the mine, the size of the excavation sites with the productivity and reliability of technical facilities, etc. are clear (Pivnyak et al., 2013; Petlovanyi et al., 2019b).

Accordingly, a characteristic feature of the technological nature of the mining enterprise is the direct relationship between production processes and mining operations (see Fig. 1), of all elements of the technological scheme.

The qualitative parameters of the mine are designed to provide certain quantitative parameters, which, in turn, require appropriate constructive and spatial properties of the qualitative parameters (Naduty et al., 2016; Dreus et al, 2016; Malanchuk et al., 2019b). From this, it follows that the change or replacement of any qualitative or quantitative parameter will affect the other technological parameters of the mine directly interconnected with it in one way or another. This influence can be cen- 
tered around most of the mining parameters and covered by the main elements of technology.

Economic indicators of the mine, depending directly or indirectly to a greater or lesser extent on all qualitative and quantitative parameters, are also assessed for their profitability which leads to changes in the mine's parameters (Wachowicz, 2010; Bilan et al., 2017).

Let us take, for example, the case of the mechanical longwall set of equipment implementation using the barrier method. Possessing high productivity, the longwall set of equipment will provide a high speed of working face advance. There is a need for a significant advance in the carrying out of preliminary developments, and in the worst case to change over the combined longwall method. This leads to an increase in the speed of carrying out preliminary developments, moreover the conditions and costs for maintaining them are also changed.

From the point of view of the expensive complex effective usage, it is necessary to take into account the mineable ore, i.e. to increase the dimensions of extraction pillars and, possibly, face length to $1000-1500 \mathrm{~m}$ and more (Stupnik 2014 et al.,; Makarov, 2017). At the same time, an increase in the working face load will require an increase in the throughput of transport and ventilation excavations, which is possible when replacing vehicles and increasing the cross-sections of excavations (Malanchuk et al., 2016). It will be necessary to increase the amount of air supplied to the working faces and development headings, i.e. increase the cross-section of general wind roadways and, possibly, upgrade or replace the mine fan (Tien, 2002; Golinko et al., 2012).

Such a relationship between the qualitative and quantitative parameters of the mine, its technological links and schematic solutions can be presented not only in technical and technological terms (Khomenko et al., 2017), but also in an economic manner (Vagonova and Volosheniuk, 2012). The economic advantages of one solution can simultaneously lead not only to advantages, but also to disadvantages in other solutions. At the same time, technological or economic advantages and disadvantages are exerted at different times (Buszko, 2009; Malanchuk, 2018).

In connection with this, the estimation for any changing parameter outside the connection with other parameters turns out to be biased and inaccurate. Proceeding from the interdependence of design solutions, the mine design is considered as a single process of all project sections and task implementation, based on a complex method of their simultaneous individual parameters' application conditions and requirements.

\section{Methodological approach}

The complex optimization method of decision making on the basis of mine mathematical representation as a whole and the use of computers is used by modern design to justify the parameters of the mines in conventional mining (Haiko, 2019) as well as unconventional mining including new methods of resource development (Lozynskyi et al., 2018a; Lozynskyi et al., 2018b; Sai et al., 2019) such as the recently widely developed technology of reclamation (Hu et al., 2014; Rysbekov et al., 2019; Kalybekov et al., 2019).

The implementation of the complex optimization method of decision making makes the collaborative parameter optimization of the coal mine possible, such as (thickness, service life, allotment size), opening schemes, preparation and mining methods, ventilation and transport schemes with simultaneous determination of rational cuts of mine roadway network, mechanical means and others (Sontamino and Drebenstedt, 2014; Hu et al., 2014).

The simultaneous study of any design solution's influence, the level and importance of any mine parameter and individual elements of the technological scheme on the generalized performance criterion give grounds for finding and choosing the most economical and technically feasible parameter (Sarycheva et al., 2003). The water filtration problem in conjunction with rock massif stability should also be taken into account (Moshynsky, 2001; Chui et al., 2018; Kuzlo et al., 2018; Bomba et al., 2018). At the same time, the complex mining parameters' optimization turns into a complex task, both logically and mathematically, especially if one starts from the idea of a mine as a developing object. Obviously, for different mine parameters and elements of its technological schemes, the solution's approval form at the neighboring stages will not be the same. Optimizing the stages and determining the optimal mine development path with all possible quantitative and qualitative parameters is not realistic because of the huge scale of the model, the insufficient accuracy of the initial information at the remote stages, etc. (Shashenko et al., 2009; Vladyko et al., 2012; Bondarenko et al., 2013).

It is possible to determine the best method of mine development, and the evolution of its qualitative parameters under certain optimal quantitative parameters (Wang et al., 2019; Sribna et al., 2019). However, the very definition of the optimum quantitative mining parameters and technological scheme elements are possible only after determining the qualitative parameters and, in particular, the optimal mine development path. A logical sequence that makes the optimization procedure really acceptable and simple through a step-by-step design, results in a method of consistent harmonizationoptimization.

The application of this method is caused both by logical difficulties and optimization algorithm calculations. As is well known (Kolokolov et al., 2005), coal reserve development can be represented as the transition of a mine from the state $S_{0}$ to the state $S_{m}$ with the help of some controls: 


$$
\begin{aligned}
& \left\{U_{1}\right\} \quad\left\{U_{i}\right\} \quad\left\{U_{m-1}\right\}
\end{aligned}
$$

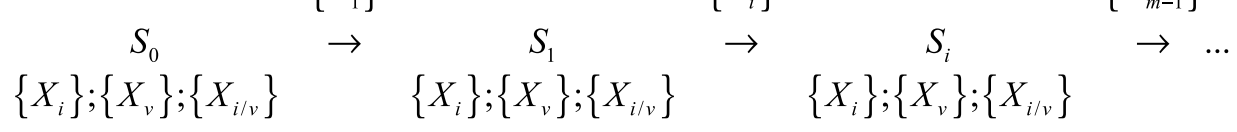

$$
\begin{aligned}
& \cdots \rightarrow \underset{\left\{X_{i}\right\} ;\left\{X_{v}\right\} ;\left\{X_{i / v}\right\} \stackrel{\left\{U_{m}\right\}}{\rightarrow}}{S_{i-1}} \underset{\left\{X_{i}\right\} ;\left\{X_{v}\right\} ;\left\{X_{i / v}\right\}}{S_{m}}
\end{aligned}
$$

where:

$\left\{X_{i}\right\} \quad$ - a set of mining parameters and characteristics which are not changed passing from one state to another; these are invariable parameters, which may consist of the previously accepted controls (for example, the opening scheme with vertical pillars),

$\left\{X_{v}\right\}-$ a set of parameters and characteristics (including mining and geological conditions), variables in system transition from one state to another,

$\left\{X_{i / \nu}\right\}$ - a set of parameters and characteristics of variables in one part and invariables in another,

$S_{0} \quad$ - the initial state of the system,

$S_{i} \quad$ - the set of conditions, specific for the $i$-st development stage of the field development,

$S_{m} \quad$ - the final mine condition, accepted for approach,

$\left\{U_{1}\right\}$ - the set of possible controls used to transit $\left\{U_{i}\right\}$ system from $S_{i-1}$ states to the $S_{m}$ states.

The task is that with the help of optimal controls $U^{0}{ }_{1}$, $U_{i}^{0}, U^{0}$, individuated from the variety of available ones, to find the algorithm of optimal mine (system) states, which are also distinguished from the variety of possible ones. In other words, we have the following proportion: The sign " $\in$ " denotes: "to be the part of", "belong to the variety":

$$
\begin{aligned}
& U_{1}^{*} \quad U_{i}^{*} \quad U_{m-1}^{*} \quad U_{m}^{*} \\
& S^{*}{ }_{0} \rightarrow S_{1}^{*} \rightarrow \ldots \rightarrow S_{i}^{*} \rightarrow \ldots \rightarrow S_{m-1}^{*} \rightarrow S_{{ }^{*}}^{*} \text {. } \\
& S_{i}^{*} \in\left\{S_{i}\right\}, \quad U^{*} \in\left\{U_{i}\right\}
\end{aligned}
$$

Probably, an absolutely optimal sequence of states with corresponding controls will be possible only for certain values of the invariable and variable parameters that characterize the mine state and make up the conditions for its existence in these states. Some values of the parameters, which we call optimal, should be distinguished from the variety of possible ones, i.e.

$$
\left\{X_{i}^{*} ; X^{*} ; X^{*}{ }_{i / v}\right\} \in\left\{X_{i} ; X_{v} ; X_{i / v}\right\} .
$$

However, the parameters themselves and the states characteristics largely depend on the order and alternation of the mining operations state change in the mine. Therefore, it is necessary to isolate the optimal sequence of states (the optimal mine development way), which is a function of the optimal parameters; which depend on the optimal method of mine development:

$$
\begin{gathered}
S^{*} \rightarrow \ldots \rightarrow S_{i}^{*} \rightarrow \ldots \rightarrow S_{m}^{*}=f\left\{X_{i}^{*} ; X_{v}^{*} ; X_{i / v}^{*}\right\}, \\
S_{i}^{*} \in\left\{S_{i}\right\} ; \quad\left\{X_{i}^{*} ; X_{v}^{*} ; X_{i / v}^{*}\right\} \in\left\{X_{i} ; X_{v} ; X_{i / v}\right\}, \\
\left\{X_{i} ; X_{v} ; X_{i / v}\right\}=f\left(\left\{S_{0}\right\} \rightarrow \ldots \rightarrow\left\{S_{i}\right\} \rightarrow \ldots \rightarrow\left\{S_{m}\right\}\right) .
\end{gathered}
$$

To transfer the system from one optimal state to another, it is necessary to apply the optimal control, the value and the form of which are also individuated from the set $U_{i}^{0} \in\left\{U_{i}\right\}$. As a result, the problem is difficult to solve, since multiplying combinations from sets by the set $\left\{U_{i}\right\}$ gives an enormous number of system states variants.

Thus, the intractable task of optimizing a stage-bystage design model as a whole becomes solvable when it is divided into two connected sequential parts. The first part of the task is performed with the primary application of logical justification methods, the engineering analysis of a significant number of competing parameter combinations, while completing the task requires great human participation in the preparation of the initial data and in the calculations.

The second part of the task is characterized with the use of predominantly numerical methods and it is necessary to use a sufficiently powerful computer when solving it. At this stage, human participation in the calculations is insignificant.

The sequential searching and selection of qualitative and quantitative parameters do not abolish the complex approach to their justification. The interrelations between them are taken into account at both stages of the solution of the problem as a whole.

\section{Results and Discussion}

\subsection{Multivariance solutions in coal mine design}

The mine as an operating mining enterprise is a set of many interrelated production processes and operations carried out with the help of machines and mechanisms according to a certain technological scheme. The general production processes interface circuit in a single continuous interaction through excavations and mechanization which means they can be defined as a technological scheme of the mine. Its main elements are opening and 


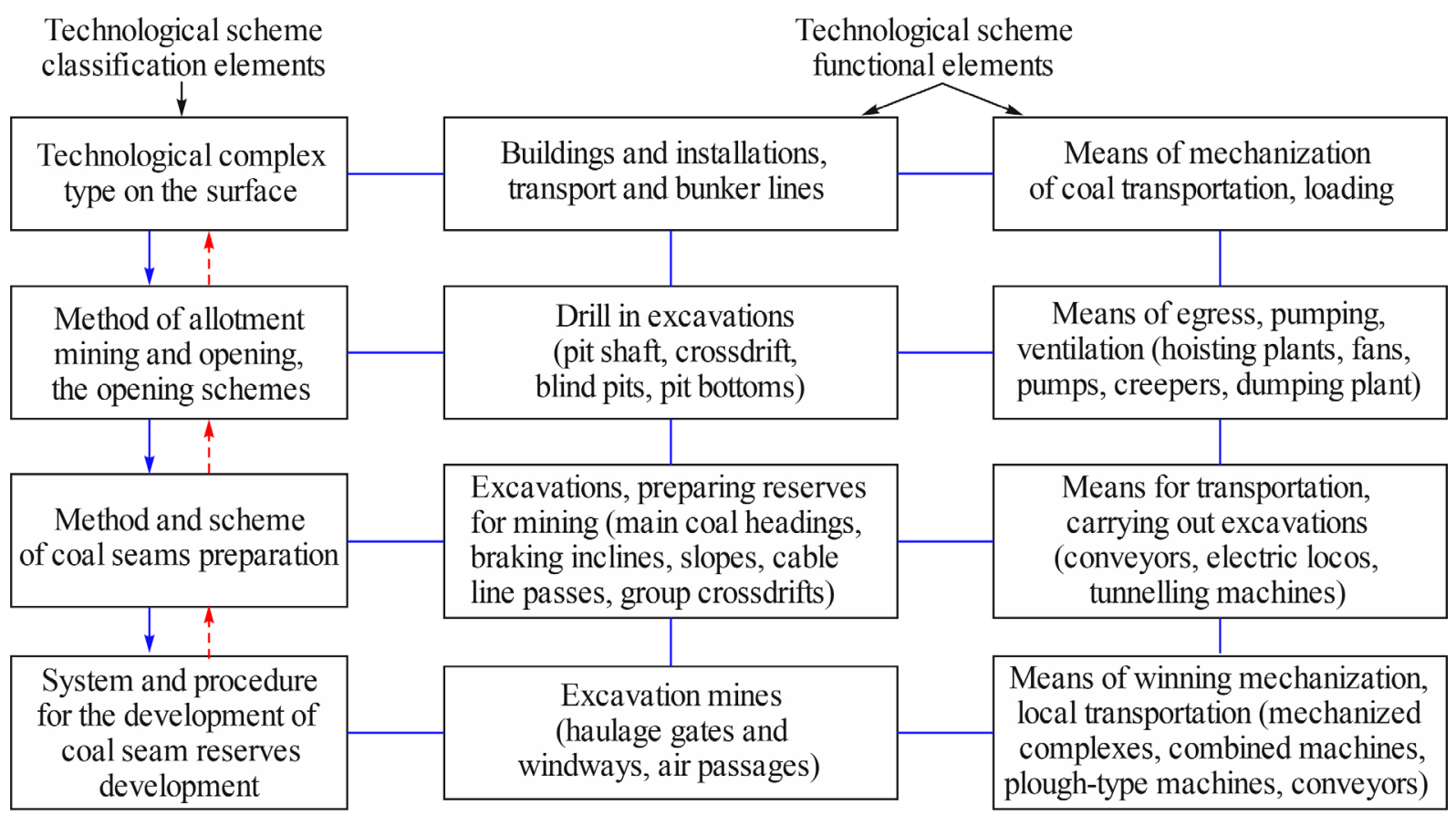
- - - Discrete relations (links) Continuous relations (links)

Figure 2: Block diagram of the mine technological scheme main elements; total arrowed line - rigid connections, dotted ones - connections, taking into account some influence on the choice of solutions

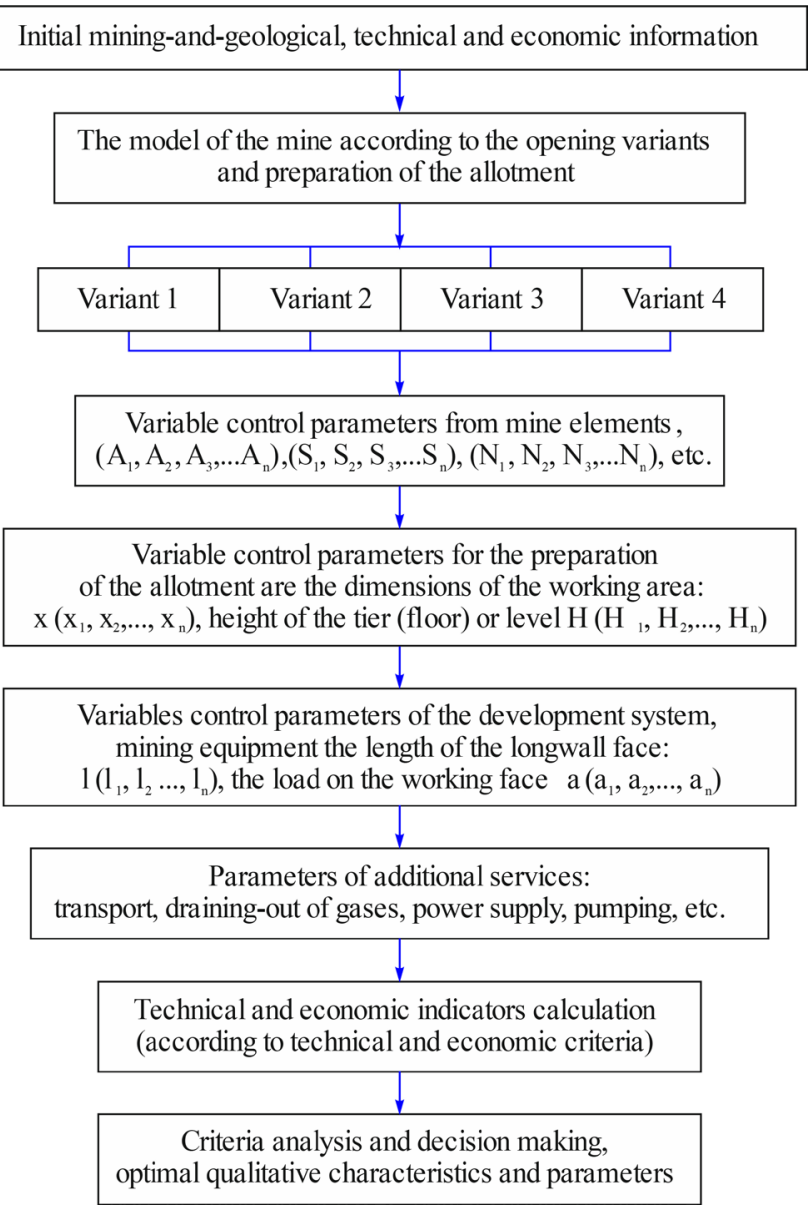

Figure 3: Block diagram of the design case formation preparing excavations, pit bottoms, pumping, transformer and other pits, transport and wind roadways, machines, stands and mechanisms (see Fig. 2).

Therefore, the technological scheme variant development comes down to the formation of qualitatively different combinations: the method and the scheme of opening, the method and scheme of preparation, the scheme of ventilation, the scheme of transport and hoisting in the whole representing a certain scheme. Such a multitude of technological chain variants, qualitatively different on any element, will be called a set of calculated variants. It is convenient to present this set of designed technological scheme variants of the mine in the form of block diagrams (see Fig. 3), thus providing clarity. In addition, such block diagrams display many competing variants, increasing the objectivity of their joint and complex comparison.

A lot of technological and areal-geological factors affect the overall topology (spacing arrangement) of all excavations, the general layout of the mechanization means and equipment in the mine. A generalized picture of the drill in excavations, the main transport-lifting and ventilation means a location is provided with a method and opening schemes. The general topology of the preliminary developments (main or level drift, braking inclines and slopes, cable line passes, air pits, etc.) is predetermined by the preparation method and layout, as well as the arrangement of transport means in the mine field, the placement of energy supplies and others. 


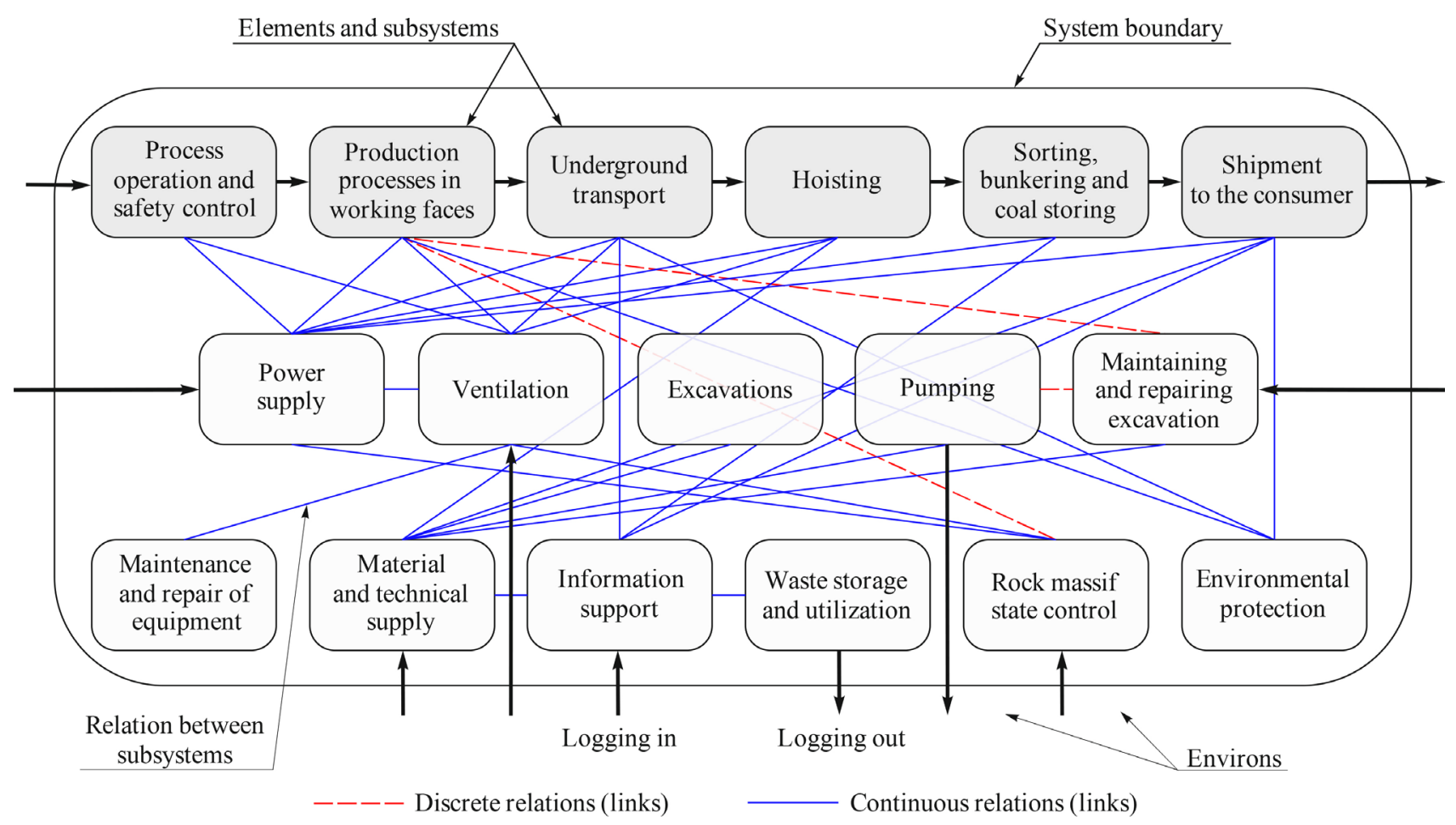

Figure 4: Model of an underground coal mining system

The design solution for any of the listed elements of the technological scheme, leading to constructive and areal features, to different location of excavations, various mechanization means implementation, the order of mining, etc., is a qualitative parameter (characteristic) of the mine.

\subsection{Design of the technological scheme of mineral deposits for underground mining}

The technological scheme consists of both individual elements and subsystems. Its condition is characterized by qualitative and quantitative parameters.

Qualitative parameters include:

- scheme and method of opening;

- scheme and method of allotment preparation;

- ventilation and transport schemes;

- development system;

- means of production processes mechanization;

- procedure of extraction and excavation sites.

Quantitative parameters include:

- mining enterprise capacity;

- load on the working face;

- sizes of working faces, level drifts, panels, levels;

- the number of simultaneous working faces on mineral deposits (seams), level, panel or block.

The technological system setting or the mining and geological characteristics is changed discretely and its state is determined over time (see Fig. 4). The setting state depends on the areal location of the reserves.
Their variability is of an accidental nature because of insufficient study degree by geological methods. Mining and geological conditions have a direct impact on the effective functioning of the technological scheme with both qualitative and quantitative parameters, such as:

- the allotment configuration and its dimensions;

- its location and mineral deposit (seam) quantity;

- distribution of reserves in the allotment;

- hypsometry of mineral occurrence, their thickness and angle of occurrence;

- the depth of mining;

- gas content;

- susceptibility to gas-dynamic phenomena;

- physical and mechanical properties of the massif and mineral resources.

The technological system setting of underground coal mining varies discretely. Its state is determined over time and depends on the areal location of reserves.

Designers should learn to keep an open mind, without focusing on stereotypes, but they should apply various methods of options, while keeping a few options for the preparation of new excavation fields. For example, according to the classical method when designing coal reserve mining with long faces for an uprising with direct airing, it is necessary to have two permanent workings at the top of the level, and two below. Using a comprehensive approach, the main surveyor and the chief technologist are challenged according to the completeness of the minerals extraction, layout across the pitch or rise of seams with the formation of topological networks of ex- 
cavations, moreover, in specific mining and geological conditions with a large number of geological faulting. There, additional ventilation, transport, drainage workings are projected along the shortest distance to the point of the nearest permanent workings with the appropriate purpose.

"Mining engineering" is very important in the process of gobbing-up and their reference marks in order to determine which section, under what slope will they be conducted in for the highest quality of pumping, air circulation, air consumption, motive column and fan mode, delivery of people and materials, cargo transportation, and reduction of the transport chain. Redistributing costs in time and space helps to arrange mine workings correctly and make the most of the investments from investors. Intelligent alternatives for further mining are taken collegially by the departments of safety and labor protection, chief engineer, chief geologist, chief technologist, chief surveyor, chief of underground and conveyor transport, chief power engineer, chief economist, chief ecologist, representatives of the general management and investors, as well as other specialist designers. It is clear that the manager's decisions are made to reduce costs and the price of mining minerals at all stages of designing.

The balance of production capacity, business plans and public demand of the country in coal in the near future should be determined. Algorithms of design developments will be required in designing underground industrial or building places. Those who do not create their own "Project" necessarily become a part of someone else's, and go down the drain.

\section{Conclusions}

When designing new levels of coal mines, it is possible to take into account all influencing factors only when modelling a technology system with logical and mathematical dependencies that describe physical phenomena. A systematic approach to multivariance solutions are taken into consideration in mining design, regarding the main influencing factors, which contributes to the direct orientation of the technological scheme choice in their diversity.

Multivariance solutions in new coal mine level designing, which are based on the theoretical, methodological and organizational basis for mine design and their technological elements, methods of optimal parameters for the further development of mines, in which the interaction of working face and preliminary development, transport and hoisting, ventilation and power supply, management apparatus, maintenance service lead to a highly efficient operation of the entire enterprise.

The described aspects indicate that an essentially new approach for finding multivariance solutions in designing new levels of coal mines is needed and should be adopted for coal resource development.

\section{Acknowledgements}

This work was supported by the Ministry of Education and Science of Ukraine, grant No. 0119U000248 and No. 0120U102084. The authors would like to thank the staff of the Translation Department from the Dnipro University of Technology for their language editing of the article. At the same time, we express gratitude to the reviewers for the valuable recommendations that have been taken into account to significantly improve the quality of this paper.

\section{References}

Aitkazinova, S., Soltabaeva, S., Kyrgizbaeva, G., Rysbekov, K., and Nurpeisova, M. (2016): Methodology of assessment and prediction of critical condition of natural-technical systems. International Multidisciplinary Scientific GeoConference Surveying Geology and Mining Ecology Management, SGEM 2, 3-10. https://doi.org/10.5593/ sgem2016/b22/s09.001

Bilan, Y., Mishchuk, H., and Dzhyhar, T. (2017): Human capital factors and remuneration: Analysis of relations, modelling of influence. Business: Theory and Practice, 18, 208214. https://doi.org/10.3846/btp.2017.022

Bomba, A., Tkachuk, M., Havryliuk, V., Kyrysha, R., Gerasimov, I., and Pinchuk, O. (2018): Mathematical modelling of filtration processes in drainage systems using conformal mapping. Journal of Water and Land Development, 39, 1, 11-15. https://doi.org/10.2478/jwld-2018-0054

Bondarenko, V., Kovalevs'ka, I., and Ganushevych, K. (2014): Progressive technologies of coal, coalbed methane, and ores mining, Book, 523. https://doi.org/10.1201/b17547

Bondarenko, V., Symanovych, H., Kicki, J., Barabash, M., and Salieiev, I. (2019): The influence of rigidity of the collapsed roof rocks in the mined-out space on the state of the preparatory mine workings. Mining of Mineral Deposits, 13, 2, 27-33. https://doi.org/10.33271/mining13.02.027

Bondarenko, V.I., Kharin, Ye.N., Antoshchenko, N.I., and Gasyuk, R.L. (2013): Basic scientific positions of forecast of the dynamics of methane release when mining the gas bearing coal seams. Scientific Bulletin of National Mining University, 5, 24-30.

Bustin, R.M. (1988): Coal exploration, mine planning and development. International Journal of Coal Geology, 9, 4, 399-400. https://doi.org/10.1016/0166-5162(88)90036-5

Buszko, A. (2009): The Impact of Coal Mining Liquidation on Population Structure in the Selected Regions of Russia and Ukraine. Olsztyn Economic Journal, 4, 2, 159-172. https:// doi.org/10.2478/v10021-009-0014-2

Chui, Y.V., Moshynskyi, V.S., Martyniuk, P.M., and Stepanchenko, O.M. (2018): On conjugation conditions in the filtration problems upon existence of semipermeable inclusions. JP Journal of Heat and Mass Transfer, 15, 3, 609619. https://doi.org/10.17654/hm015030609

Dreus, A.Yu., Sudakov, A.K., Kozhevnikov, A.A., and Vakhalin, Yu.N. (2016): Study on thermal strength reduction of rock formation in the diamond core drilling process using pulse flushing mode. Scientific Bulletin of National Mining University, 3, 5-10. 
Galiyev, S.Zh., Dovzhenok, A.D., Kol'ga, A.S., Galiyev, D.A., and Uteshov, E.T. (2019): Digitalization and the potential for improving the design and planning of mining operations in open cast mining. News of the National Academy of Sciences of the Republic of Kazakhstan, Series of Geology and Technical Sciences. Preprint.

Golinko, V.I., Luts, I.O., and Yavorskaya, Ye.A. (2012): Reserch of air and dust balance in inclined shaft of the mine N. 9-10 at manganese dressing plant. Scientific Bulletin of National Mining University, 3, 98-101

Griadushchiy, Y., Korz, P., Koval, O., and Bondarenko, V. (2007): Advanced Experience and Direction of Mining of Thin Coal Seams in Ukraine. Technical, Technological and Economical Aspects of Thin-Seams Coal Mining, International Mining Forum, 2007, 2-7. https://doi.org/10.1201/ noe 0415436700.ch1

Haiko, H., Saik, P., and Lozynskyi, V. (2019): The Philosophy of Mining: Historical Aspect and Future Prospect. Philosophy \& Cosmology, 22, 76-90.

$\mathrm{Hu}, \mathrm{Z}$., Xiao, W., and Fu, Y. (2014): Introduction to Concurrent Mining and Reclamation for Coal Mines in China. Mine Planning and Equipment Selection, 781-789. https:// doi.org/10.1007/978-3-319-02678-7_76

Jain, R.K., Cui, Z.C, and Domen, J.K. (2016): Environmental Management System Implementation in the Mining Industry. Environmental Impact of Mining and Mineral Processing, 35-52. https://doi.org/10.1016/b978-0-12-8040409.00003-6

Kalinichenko, V., Pysmennyi, S., Shvaher, N., Kalinichenko, O. (2018): Selective underground mining of complex structured ore bodies of Kryvyi Rih Iron Ore Basin. E3S Web of Conferences, 60, 00041 https://doi.org/10.1051/ e3sconf $/ 20186000041$

Kalybekov, T., Rysbekov, K.B., Toktarov, A.A., Otarbaev, O.M. (2019): Underground mine planning with regard to preparedness of mineral reserves. Mining Informational and Analytical Bulletin, 5, 34-43.

Kalybekov, T., Sandibekov, M., Rysbekov, K., and Zhakypbek, Y. (2019): Substantiation of ways to reclaim the space of the previously mined-out quarries for the recreational purposes. E3S Web of Conferences, 123, 01004. https:// doi.org/10.1051/e3sconf/201912301004

Khomenko, O.Ye., Sudakov, A.K., Malanchuk, Z.R., and Malanchuk, Ye.Z. (2017): Principles of rock pressure energy usage during underground mining of deposits. Naukovyi Visnyk Natsionalnoho Hirnychoho Universytetu, 2, 158, 34-43.

Khomenko, O.Y., Kononenko, M.M., Myronova, I.G., Sudakov, A.K. (2018): Increasing ecological safety during underground mining of iron-ore deposits. Naukovyi Visnyk Natsionalnoho Hirnychoho Universytetu, 2, 29-38. https:// doi.org/10.29202/nvngu/2018-2/3

Kolokolov. (2005): Technology of underground mining of mineral deposits. Dnipro: National Mining University.

Kovalevska, I., Zhuravkov, M., Chervatiuk, V., Husiev, O., and Snihur, V. (2019): Generalization of trends in the influence of geomechanics factors on the choice of operation modes for the fastening system in the preparatory mine workings. Mining of Mineral Deposits, 13, 3, 1-10. https:// doi.org/10.33271/mining13.03.001

Kuzlo, M.T., Moshynskyi, V.S., Martyniuk, P.M. (2018): Mathematical modelling of soil massif's deformations under its drainage. International Journal of Applied Mathematics, 31, 6, 751-762. https://doi.org/10.12732/ijam.v31i6.5

Lozynskyi, V., Dychkovskyi, R., Saik, P., Falshtynskyi, V. (2018): Coal Seam Gasification in Faulting Zones (Heat and Mass Balance Study): Solid State Phenomena, 277, 66-79. https://doi.org/10.4028/www.scientific.net/SSP.277.66

Lozynskyi, V., Saik, P., Petlovanyi, M., Sai, K., Malanchuk Z., and Malanchyk, Ye. (2018): Substantiation into mass and heat balance for underground coal gasification in faulting zones. Inzynieria Mineralna, 19, 2, 289-300. http://doi. org/10.29227/IM-2018-02-36

Lozynskyi, V.G., Dychkovskyi, R.O., Falshtynskyi, V.S., Saik, P.B., and Malanchuk, Ye.Z. (2016): Experimental study of the influence of crossing the disjunctive geological faults on thermal regime of underground gasifier. Naukovyi Visnyk Natsionalnoho Hirnychoho Universytetu, 5, 21-29.

Makarov, V.M. (2017): Mathematical model of the optimization of the technological development of coal mining in Ukraine. The Problems of General Energy, 1, 16-23. https://doi.org/10.15407/pge2017.01.016

Malanchuk, Ye., Korniienko, V., Moshynskyi, V., Soroka, V., Khrystyuk, A., and Malanchuk, Z. (2019b): Regularities of hydromechanical amber extraction from sandy deposits. Mining of Mineral Deposits, 13, 1, 49-57. https://doi. org/10.33271/mining 13.01.049

Malanchuk, Z. (2018): Modeliuvannia procesu utvorennia zon koncentracii pidvyshchenoho vmistu metalu $\mathrm{v}$ tekhnohennykh rodovyshchakh. Rozrobka Rodovyshch, 12, 2, 76-84.

Malanchuk, Z., Korniyenko, V., Malanchuk, Y., and Khrystyuk, A. (2016): Results of experimental studies of amber extraction by hydromechanical method in Ukraine. Eastern-European Journal of Enterprise Technologies, 10, 81, 24-32 https://doi.org/10.15587/1729-4061.2016.72404

Malanchuk, Z.R., Moshynskyi, V.S., Korniienko, V.Y., Malanchuk, Y.Z., and Lozynskyi, V.H. (2019a): Substantiating parameters of zeolite-smectite puff-stone washout and migration within an extraction chamber. Naukovyi Visnyk Natsionalnoho Hirnychoho Universytetu, 6, 11-18. https:// doi.org/10.29202/nvngu/2019-6/2

Maldynova, A., Osmanov, Z., and Galiyev, D. (2018): Formation of marketing strategy for promoting an innovative product. Journal of Applied Economic Sciences, 13, 7, 1951-1958.

Moshynsky, V. (2001): Modern water conditions in the northwest part of Ukraine: An analysis. Water Engineering and Management, 148, 4, 22-26

Murray, J.A. (1997): Economic impact of current environmental regulations on mining. Mining Environmental Handbook, 630-641. https://doi.org/10.1142/9781860943768 -0015

Mustafin, S.A., Duisen, G.M., Zeinullin, A.A., Korobova, E.V. (2019). Evaluation of the choice of borrower rating groups. News of the National Academy of Sciences of the Republic of Kazakhstan, Series of Geology and Techni- 
cal Sciences, 6(438). https://doi.org/10.32014/2019.2518170X.166

Naduty, V., Malanchuk, Z., Malanchuk, Y., and Korniyenko, V. (2016): Research results proving the dependence of the copper concentrate amount recovered from basalt raw material on the electric separator field intensity. Eastern-European Journal of Enterprise Technologies, 5, 83, 19-24. https://doi.org/10.15587/1729-4061.2016.79524

Petlovanyi, M., Kuzmenko, O., Lozynskyi, V., Popovych, V., Sai, K., and Saik, P. (2019a): Review of man-made mineral formations accumulation and prospects of their developing in mining industrial regions in Ukraine. Mining of Mineral Deposits, 13, 1, 24-38. https://doi.org/10.33271/ mining13.01.024

Petlovanyi, M., Lozynskyi, V., Zubko, S., Saik, P., and Sai, K. (2019b): The influence of geology and ore deposit occurrence conditions on dilution indicators of extracted reserves. Rudarsko Geolosko Naftni Zbornik, 34, 1, 83-91. https://doi.org/10.17794/rgn.2019.1.8

Petlovanyi, M.V., Lozynskyi, V.H., Saik, P.B., and Sai, K.S. (2018): Modern experience of low-coal seams underground mining in Ukraine. International Journal of Mining Science and Technology, 28, 6, 917-923. https://doi. org/10.1016/j.ijmst.2018.05.014

Pivnyak, G., Dychkovskyi, R., Smirnov, A., and Cherednichenko, Y. (2013): Some aspects on the software simulation implementation in thin coal seams mining. Energy Efficiency Improvement of Geotechnical Systems, 1-10. https://doi.org/10.1201/b16355-2

Pivnyak, G.G., Pilov, P.I., Bondarenko, V.I., Surgai, N.S., and Tulub, S.B. (2005): Development of coal industry: The part of the power strategy in the Ukraine. Gornyi Zhurnal, $5,14-17$.

Piwniak, G.G., Bondarenko, V.I., Salli, V.I., Pavlenko, I.I., and Dychkovskiy, R.O. (2007): Limits to economic viability of extraction of thin coal seams in Ukraine. Technical, Technological and Economic Aspects of Thin-Seams Coal Mining International Mining Forum 2007, 129-132. https:// doi.org/10.1201/noe0415436700.ch16

Rysbekov, K., Huayang, D., Kalybekov, T., Sandybekov, M., Idrissov, K., Zhakypbek, Y., Bakhmagambetova, G. (2019): Application features of the surface laser scanning technology when solving the main tasks of surveying support for reclamation. Mining of Mineral Deposits, 13, 3, 40-48. https://doi.org/10.33271/mining13.03.040

Sai, K., Malanchuk, Z., Petlovanyi, M., Saik, P., and Lozynskyi, V. (2019): Research of Thermodynamic Conditions for Gas Hydrates Formation from Methane in the Coal Mines. Solid State Phenomena, 291, 155-172. https://doi. org/10.4028/www.scientific.net/SSP.291.155

Saik, P., Petlevanyi, M., Lozynskyi, V., Sai, K., and Merzlikin, A. (2018): Innovative approach to the integrated use of energy resources of underground coal gasification. Solid State Phenomena, 277, 221-231. https://doi.org/10.4028/ www.scientific.net/SSP.277.221

Sarycheva, L. (2003): Using GMDH in ecological and socio-economical monitoring problems. Systems Analysis Modelling Simulation, 43, 10, 1409-1414. https://doi.org/ $10.1080 / 02329290290024925$
Shashenko, A., Gapieiev, S., Solodyankin, A. (2009): Numerical simulation of the elastic-plastic state of rock mass around horizontal workings. Archives of Mining Sciences, 54, 2, 341-348.

Singhal, R.K. (1985): Mining planning and equipment selection in coal mining. https://doi.org/10.4095/304824

Sontamino, P., and Drebenstedt, C. (2014): A Prototype Decision Making Tool of Coal Mine Planning Using System Dynamics Model. Mine Planning and Equipment Selection, 1475-1484. https://doi.org/10.1007/978-3-319-02678 $-7 \_142$

Sribna, Y., Trokhymets, O., Nosatov, I., and Kriukova, I. (2019): The globalization of the world coal market - contradictions and trends. E3S Web of Conferences, 123, 01044. https://doi.org/10.1051/e3sconf/201912301044

Stupnik, M., Kolosov, V., Kalinichenko, V., Pismennyi, S. (2014): Physical modeling of waste inclusions stability during mining of complex structured deposits. Progressive Technologies of Coal, Coalbed Methane, and Ores Mining, 25-30. https://doi.org/10.1201/b17547.

Stupnik, N., Kalinichenko, V., Pismennij, S., Kalinichenko, E. (2015): Features of underlying levels opening at "ArsellorMittal Kryvyic Rih" underground mine. New Developments in Mining Engineering 2015: Theoretical and Practical Solutions of Mineral Resources Mining, 39-44. https://doi.org/10.1201/b19901-8

Tien, J. (2002): Ventilation in Chinese coal mines and the new coal mine safety regulations. Mine Ventilation. https://doi. org/10.1201/9781439833742.ch96

Vagonova, O.G., and Volosheniuk, V.V. (2012): Mining enterprises' economic strategies as derivatives of nature management in the system of social relations. Scientific Bulletin of National Mining University, 2, 127-134

Vivcharenko, O. (2012): Development of coal industry of Ukraine in the context of contemporary challenges. Geomechanical Processes During Underground Mining, 1-5. https://doi.org/10.1201/b13157-2

Vladyko, O., Kononenko, M., and Khomenko, O. (2012): Imitating modeling stability of mine workings. Geomechanical Processes During Underground Mining, 147-150. https://doi.org/10.1201/b13157-26

Wachowicz, J. (2010): Possibility of production complex of sufficient gasses in Ukraine. New Techniques and Technologies in Mining, 113-119. https://doi.org/10.1201/ b11329-19

Wang, J., Bi, L., Wang, L., Jia, M., and Mao, D. (2019): A mining technology collaboration platform theory and its product development and application to support china's digital mine construction. Applied Sciences, 9, 24, https://doi. org/10.3390/app9245373

Yu, L., Yang, R., Zheng, C., and Li, S. (2019): Research on prevention and mitigation of deep mine hazards in ningzheng mining area. Paper presented at the E3S Web of Conferences, 118. https://doi.org/10.1051/e3sconf/201911804003

Zhao, C., Shi, X., Xie, S., Liu, W., He, E., Tang, Y., and Qiu, R. (2019): Ecological risk assessment of neodymium and yttrium on rare earth element mine sites in Ganzhou, China. Bulletin of Environmental Contamination and Toxicology, 103, 4, 565-570 


\section{SAŽETAK}

\section{Multivarijantna rješenja u dizajniranju novih horizonata u rudnicima ugljena}

U radu su opisana različita tehnološka rješenja kod projektiranja novih rudničkih horizonata, a kojima se povećava uspješnost inženjerskih zadataka prilikom iskapanja. Navedeni je pristup složena kombinacija kvantitativnih i kvalitativnih parametara s ciljem pripreme novoga radilišta (otkopa), potrebnih radova, prijevoza, prozračivanja, odvoda plinova te crpljenja. Tako se omogućuje ušteda tijekom svih faza pripreme i rudarenja. Rezultati su omogućili optimizaciju varijabli razradnoga sustava te racionalnu kategorizaciju rezervi ugljena, čak i tijekom promjene rudarskih i geoloških uvjeta. Na temelju istraživanja donose se zaključci o načinu primjene takvih multivarijantnih rješenja u novim rudnicima. Rezultati su s dovoljnom točnošću potvrdili praktičnu primjenu toga modela kod planiranja novih horizonata.

\section{Ključne riječi:}

rudnici ugljena, multivarijantnost, tehnološki planovi

\section{Authors contribution}

Vasyl Lozynskyi (PhD., Associated Professor): participated in all work stages, paper submission and revision, and completed literature review. Volodymyr Medianyk (PhD., Associated Professor): initialized the idea, developed a methodological approach, managed the whole process and supervised it from the beginning to the end. Pavlo Saik (PhD., Associated Professor): performed the grouping of the model of an underground coal mining system, verification and evaluation of the model. Kanay Rysbekov (PhD., Associated Professor): tested multivariance accuracy and helped with work implementation. Maksym Demydov (Mining Engineer): data analysis and graphical support. 